\title{
JEKK
}

Jurnal Epidemiologi Kesehatan Komunitas 3 (1), 2018, 18-28

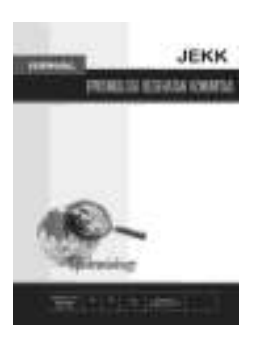

\section{Komponen Sindrom Metabolik sebagai Faktor Risiko Penyakit Ginjal Kronik Stadium Terminal (Studi di RSUP Dr.Kariadi dan RSUD Kota Semarang)}

\author{
Kartika Ikawati ${ }^{*}$, Shofa Chasani ${ }^{* *}$, Suhartono $^{* * *}$, Suharyo Hadisaputro $^{* * * *}$, \\ Selamat Budijitno** \\ *Akademi Analis Kesehatan 17 Semarang, ${ }^{* *}$ Fakultas Kedokteran Universitas Diponegoro \\ ${ }^{* * * *}$ Fakultas Kesehatan Masyarakat Universitas Diponegoro, ${ }^{* * * *}$ Politeknik Kesehatan \\ Semarang
}

\begin{abstract}
Background : End Stage Renal Disease (ESRD) has been among the top ten list of non infectious diseases frequently found at RSUP dr. Kariadi and RSUD Kota Semarang. Risk factors for ESRD are metabolic syndrome components, which are having an upward trend. This study had an objective to provided an evidence of metabolic syndrome factors that became risk factors for ESRD.

Method : This study applied an analytical observational method with a case control study design. The study used 90 respondents as samples, divided into two different groups: 45 respondents as case samples and 45 respondents as control samples with consecutive sampling. Variables in this study ware the individual characteristics and history of suffering from metabolic syndrome components. Data were collected by interview, medical record, and indepth interview. These data were subject to analyses using univariat, bivariate, and multivariate tests

Results : The study found the risk factors for ESRD as the followings: hypertension term of $>5$ years $(\mathrm{OR}=10,89$ and $95 \% \mathrm{CI}=3,08-38,59 ; \mathrm{p}=0,000)$, diabetes mellitus term of $>5$ years $(\mathrm{OR}=3,84 ; 95 \% \mathrm{CI}=1,20-12,30 ; \mathrm{p}=0,023)$, and low HDL-cholesterol history of $<35$ $\mathrm{mg} / \mathrm{dL}$ (men) and $<40 \mathrm{mg} / \mathrm{dL}$ (women) with $(\mathrm{OR}=3.123,95 \% \mathrm{CI}=1.08-9.04 ; \mathrm{p}=0,04)$. The in-depth interview resulted in adequate knowledge of the respondents about the risk factors for ESRD.

Conclusion : Risk factors for ESRD found during the observation were hypertension term of $>5$ years, diabetes mellitus term of $>5$ years, and low cholesterol HDL. To prevent the progression of chronik kidney disease required strict control of metabolic syndrome.
\end{abstract}

Keywords : Metabolic syndrome; end stage renal disease; risk factors

*Penulis korespondensi : kartika.aisha@yahoo.com 


\section{Pendahuluan}

Penyakit ginjal kronik (PGK) terminal adalah suatu sindrom klinis dengan etiologi yang beragam dan mengakibatkan penurunan fungsi ginjal yang bersifat menahun, berlangsung progresivve dan umumnya irreversible dengan Laju Filtrasi Glomerulus (LFG) $<15 \mathrm{ml} / \mathrm{menit} / 1,73 \mathrm{~m}^{2}$ yang terjadi selama 3 bulan atau lebih. ${ }^{1,2}$ Penyakit ginjal kronik terminal merupakan masalah kesehatan dunia karena insidensinya terus meningkat dengan angka kematian tinggi $(48,5 \%){ }^{3}$ Kejadian PGK terminal di rumah sakit menyebabkan kematian no 3, setelah perdarahan intrakranial dan strok. ${ }^{4}$ Data insiden dan prevalensi PGK terminal di Indonesia tidak diketahui secara pasti. Jumlah penderita diperkirakan terus meningkat. ${ }^{5}$ Penyakit ginjal kronik stadium terminal di Jawa Tengah menempati urutan ke-3 setelah DKI Jakarta dan Jawa Barat ${ }^{5}$ dengan prevalensi sebesar $0,3 \%$. $^{6}$

Penyakit ginjal kronik terminal di RSUP dr. Kariadi Semarang selalu menempati peringkat 10 besar untuk penyakit non infeksi, bahkan pada tahun 2014 menempati urutan ke-3. Demikian juga yang terjadi di RSU Kota Semarang. Jumlah kunjungan pasien PGK yang menjalani rawat jalan di RSU Kota Semarang dari tahun 2013 sampai tahun 2016 mengalami peningkatan.

Menurut Taal and Brenner ${ }^{7}$ faktor risiko PGK terminal adalah : usia tua, riwayat keluarga, etnis, jenis kelamin, diabetes melitus (DM), sindrom metabolik (SM), obesitas, dan dislipidemia Penelitian Johnson $^{8}$, mendapatkan SM terjadi pada $30,5 \%$ pasien PGK stadium 4 dan 5. Sindrom metabolik (SM) sebagai faktor risiko PGK terminal menurut World Health Organization (WHO) merupakan kondisi meliputi hipertensi (tekanan darah sistole/diastole $\quad \geq 140 / 90 \quad \mathrm{mmHg}$ ), dislipidemia (trigliserida $>150 \mathrm{mg} / \mathrm{dL}$ dan atau High Density Lipoprotein /HDL-C, $\mathrm{L}<35 \mathrm{mg} / \mathrm{dL}, \mathrm{P}<40 \mathrm{mg} / \mathrm{dL}$ ), obesitas (IMT $\geq 30$ ) dan/atau rasio perut pinggang ( $\mathrm{L}>90$, $\mathrm{P}>0.85$ ), DM tipe-2 atau toleransi glukosa terganggu (TGT) dan mikroalbuminuria $>20 \mu \mathrm{g} / \mathrm{menit}(30 \mathrm{mg} / \mathrm{gCr})$, atau dengan diagnosa klinis : DM type-2 atau Toleransi Glukusa Terganggu (TGT) dan dua kriteria diatas jika toleransi glukosa normal diperlukan 3 kriteria. ${ }^{9}$

Permasalahan yang terjadi adalah kejadian PGK terminal dan sindrom metabolik di RSUP dr.Kariadi dan RSUD Kota Semarang terus meningkat, sementara itu penelitian mengenai berbagai faktor sindrom metabolik yang berhubungaan terhadap kejadian penyakit ginjal kronik terminal di rumah sakit tersebut masih jarang dilakukan serta mendapatkan hasil yang berbeda. Manfaat penelitian ini adalah untuk menjelaskan dan membuktikan bahwa berbagai faktor sindrom metabolik berhubungan terhadap kejadian PGK stadium terminal.

\section{Metode}

Jenis penelitian ini survei analitik dengan pendekatan Case control. Tempat penelitian di RSUP dr. Kariadi Semarang dan RSUD Kota Semarang. Waktu penelitian dimulai bulan Maret -Juni 2016.

Populasi terjangkau penelitian ini adalah semua penderita penyakit ginjal kronik stadium 1-2 dan stadium terminal di RSUP dr. Kariadi dan RSUD Kota Semarang pada tahun 2016. Sampel penelitian diambil dengan teknik consecutive sampling terhadap populasi terjangkau yang memenuhi kriteria inklusi. Sampel penelitian sebanyak 90 responden yang terdiri dari 45 kasus (PGK terminal) dan 45 kontrol (PGK 1-2). Penelitian dilakukan dengan matching usia terhadap kelompok kasus dan kontrol. Analisis data dilakukan dengan uji univariat, bivariat dan multivarit.

Proses pengumpulan data dilakukan dengan instrumen kuesioner, observasi catatan medis dan wawancara mendalam untuk mendapatkan informasi mengenai riwayat menderita komponen sindrom merabolik. Variabel penelitian meliputi : riwayat keluarga menderita PGK terminal, riwayat keluarga menderita 
komponen sindrom metabolik, riwayat obesitas, riwayat jumlah batang rokok/hari, riwayat lama merokok, riwayat diabetes mellitus, riwayat hipertensi, riwayat kadar kolesterol total, riwayat kadar trigliserida, riwayat kadar HDL-kolesterol rendah, riwayat kadar LDL-kolesterol tinggi, riwayat lama diabetes mellitus, riwayat lama hipertensi dan riwayat lama dislipidemia.

\section{Hasil}

Rumah Sakit Umum Pusat (RSUP) dr. Kariadi Semarang terletak di Jalan Doktor Sutomo No. 16, Randusari, Semarang, Jawa Tengah dan merupakan rumah sakit kelas A. Saat ini RSUP dr.Kariadi Semarang memiliki 35 mesin dialisis ${ }^{10}$. Pada tahun 2013 jumlah kunjungan penderita PGK terminal rawat inap di RSUP dr. Kariadi Semarang sebanyak 699 orang, tahun 2014 sebanyak 1.527 orang, tahun 2015 sebanyak 698 orang dan tahun 2016 (Januari-April) sebanyak 198 orang. Pada tahun 2013 penderita DM rawat inap 250 orang, hipertensi 7.590 orang dan dislipidemia 496 orang. Tahun 2014 penderita DM sebanyak 724 orang, hipertensi 5.473 orang dan dislipidemia 296 orang. Jumlah penderita PGK terminal yang rutin menjalani hemodialisis pada tahun 2016 sebanyak 115 orang.

Rumah Sakit Umum Daerah (RSUD) Kota Semarang merupakan rumah sakit kelas B yang berada di J1. Ketileng Raya No.1 Semarang. ${ }^{11}$ Jumlah kunjungan pasien PGK yang menjalani rawat jalan di RSUD Kota Semarang tahun 2014 sebanyak 6.967 dan kunjungan rawat inap 271 orang. Pada bulan Januari-April tahun 2016 setiap hari teradapat 7-10 penderita PGK stadium 1-2 yang menjalani rawat inap maupun jalan. Saat ini jumlah mesin hemodialisis yang dimiliki RSUD Kota Semarang sebanyak 17 unit. Jumlah penderita PGK terminal yang rutin menjalani hemodialisis sebanyak 60 orang. Karakteristik jenis kelamin, umur, pendidikan dan pekerjaan responden penelitian dapat diketahui pada Tabel 1.
Tabel 1. Gambaran Responden Penelitian Berdasarkan Karakteristik Individu ( $\mathrm{n}=90)$

\begin{tabular}{lcccc}
\hline & Kasus & & \multicolumn{2}{c}{ Kontrol } \\
(n=45) & \\
\cline { 2 - 4 } $\begin{array}{l}\text { Karakteristik } \\
\text { Jenis Kelamin }\end{array}$ & Jumlah & $\%$ & Jumlah & $\%$ \\
\hline Laki-Laki & 28 & 62,2 & 23 & 51,1 \\
Perempuan & 17 & 37,8 & 22 & 48,9 \\
\hline Karakteristik & Jumlah & $\%$ & Jumlah & $\%$ \\
Umur & & & & \\
\hline 17-25 & 1 & 2,2 & 1 & 2,2 \\
26-35 & 3 & 6,7 & 3 & 6,7 \\
36-45 & 10 & 22,2 & 7 & 15,6 \\
46-55 & 14 & 31,1 & 16 & 35,6 \\
56-65 & 12 & 26,7 & 14 & 31,1 \\
>65 & 5 & 11,1 & 4 & 8,9 \\
\hline Karakteristik & Jumlah & $\%$ & Jumlah & $\%$ \\
Pendidikan & & & & \\
\hline SD/Sederajad & 7 & 15,6 & 5 & 11,1 \\
SMP/Sederajad & 2 & 4,4 & 6 & 13,3 \\
SMA/Sederajad & 19 & 42,2 & 19 & 42,2 \\
Sarjana & 17 & 37,8 & 15 & 33,3 \\
\hline Karakteristik & Jumlah & $\%$ & Jumlah & $\%$ \\
Pekerjaan & & & & \\
\hline Pensiun/Tidak & & & & \\
bekerja & 18 & 40 & 3 & 6,7 \\
Pegawai swasta & 8 & 17,8 & 13 & 28,8 \\
Wiraswasta & 13 & 28,9 & 12 & 26,7 \\
PNS & 6 & 13,3 & 13 & 31,1 \\
Petani & 0 & 0 & 3 & 6,7 \\
\hline Total & 45 & 100 & 45 & 100 \\
\hline & & & & \\
\hline
\end{tabular}

Pada Tabel 1, penderita PGK terminal lebih banyak yang berjenis kelamin laki-laki $(62,2 \%)$ daripada perempuan $(37,8 \%)$. Usia penderita PGK terminal dan PGK stadium 1-2 paling banyak 46-55 tahun (katagori lansia awal). Sedangkan yang paling sedikit 7-25 tahun (katagori remaja akhir). Tingkat pendidikan penderita PGK terminal terbanyak adalah SMA/sederajad yaitu 19 orang (42,2 \%), dan paling sedikit SMP, sebesar 2 orang $(4,4 \%)$. Sedangkan jenis pekerjaan penderita PGK-terminal paling banyak tidak bekerja/pensiun yaitu 18 orang $(17,8 \%)$. 
Gambaran distribusi rata-rata hasil pemeriksaan kondisi klinis pada kelompok kasus dan kontrol dapat diketahui dari Tabel 2.

Tabel 2. Gambaran Responden Penelitian Berdasarkan Kondisi Klinis

\begin{tabular}{|c|c|c|c|}
\hline & Kasus $(n=45)$ & Kontrol $(n=45)$ & \\
\hline Variabel & $\overline{\text { Mean } \pm \text { SD }}$ & Mean \pm SD & $P$ \\
\hline \multirow[t]{2}{*}{$\overline{\text { Usia (tahun) }}$} & $51,51 \pm 12,297$ & $52,22 \pm 11,994$ & 0,782 \\
\hline & $26,72 \pm 4,347$ & $25,14 \pm 3,650$ & 0,079 \\
\hline \multicolumn{4}{|l|}{$\begin{array}{l}\text { Indeks massa } \\
\text { tubuh }\left(\mathrm{kg} / \mathrm{m}^{2}\right)\end{array}$} \\
\hline & $2,47 \pm 6,499$ & $1,04 \pm 3,296$ & 0,842 \\
\hline & $1,84 \pm 4,487$ & $2,58 \pm 6,458$ & 0,942 \\
\hline Kadar gula darah (mg/dL) & $177 \pm 103,079$ & $135 \pm 75,63$ & 0,594 \\
\hline $\begin{array}{l}\text { Tekanan darah } \\
\text { - Sistole }(\mathrm{mmHg})\end{array}$ & $152 \pm 27,149$ & $133 \pm 16,77$ & $0,001^{*}$ \\
\hline - Diastole (mmHg) & $92 \pm 9,378$ & $85 \pm 7,83$ & $0,000 *$ \\
\hline Kadar kolesterol total (mg/dL) & $\begin{array}{l}194 \pm 57,408 \\
174 \pm 92,683\end{array}$ & $\begin{array}{l}167 \pm 62,818 \\
132 \pm 60,866\end{array}$ & $\begin{array}{l}0,048^{*} \\
0,007^{*}\end{array}$ \\
\hline Kadar irigirserida (mg/aL) & $7 \pm 7,97$ & $3 \pm 6,458$ & $0,008 *$ \\
\hline (2) & $6 \pm 6,419$ & $1 \pm 1,848$ & $0,000 *$ \\
\hline Lama dislipidemia (tahun) & $1,58 \pm 0,499$ & $1,78 \pm 3,059$ & $0,012^{*}$ \\
\hline
\end{tabular}
Nilai $p<0,05$

Berdasarkan Tabel 2 diketahui bahwa ratarata usia kelompok kasus dan kontrol berimbang. Riwayat IMT pada kelompok kasus rata-rata $26,72 \mathrm{~kg} / \mathrm{m}^{2}$, sedikit lebih besar dibandingkan kelompok kontrol $25,14 \mathrm{~kg} / \mathrm{m}^{2}$. Data riwayat jumlah rokok yang diisap responden kelompok kasus hanya 2 batang/hari dan pada kelompok kontrol 1 batang/hari.Rata-rata lama merokok kelompok kasus justru lebih pendek dibanding kelompok kontrol. Ratarata tekanan darah, kadar gula darah, kolesterol total, trigliserida, lama Dm, lama hipertensi dan lama dislipidemia pada kelompok kasus lebih besar daripada kelompok kontrol. Hasil uji bivariat hubungan variabel penelitian dengan kejadian PGK terminal dapat diketahui pada Tabel 3. 
Tabel 3. Hasil Uji Bivariat Variabel Penelitian dengan Kejadian PGK terminal

\begin{tabular}{|c|c|c|c|c|c|c|c|}
\hline \multirow[t]{2}{*}{ Variabel } & \multicolumn{2}{|c|}{$\begin{array}{c}\text { Kasus (PGK } \\
\text { terminal) }\end{array}$} & \multicolumn{2}{|c|}{$\begin{array}{c}\text { Kontrol } \\
\text { ( PGK 1-2) }\end{array}$} & \multirow[t]{2}{*}{ OR } & \multirow[t]{2}{*}{$95 \% \mathrm{CI}$} & \multirow[t]{2}{*}{$P$} \\
\hline & $\mathrm{n}$ & $\%$ & $\mathrm{n}$ & $\%$ & & & \\
\hline \multicolumn{8}{|l|}{ Riwayat Keluarga PGK-V } \\
\hline Ada & 3 & 6,7 & 2 & 4,4 & 1,54 & $0,24-9,66$ & 1,000 \\
\hline Tidak & 42 & 93,3 & 43 & 95,6 & & & \\
\hline \multicolumn{8}{|c|}{ Riwayat Keluarga Sindrom metabolik } \\
\hline Ada & 29 & 64,4 & 19 & 42,2 & 2,48 & $1.06-5.80$ & 0,057 \\
\hline Tidak ada & 16 & 35,6 & 26 & 57,8 & & & \\
\hline \multicolumn{8}{|l|}{ Riwayat obesitas IMT $\geq 30$} \\
\hline Ada & 11 & 24,4 & 6 & 13,3 & 2.10 & $0.70-6.29$ & 0.281 \\
\hline Tidak ada & 34 & 75,6 & 39 & 86,7 & & & \\
\hline \multicolumn{8}{|l|}{ Riwayat batang rokok/hari } \\
\hline$\geq 20$ & 4 & 8,9 & 1 & 2,2 & 4,29 & $0,46-40,01$ & 0,357 \\
\hline$<20(0-20)$ & 41 & 91,1 & 44 & 97,8 & & & \\
\hline \multicolumn{8}{|l|}{ Riwayat Lama merokok } \\
\hline$\geq 5$ tahun & 8 & 17,8 & 7 & 15,6 & 1,17 & $0,39-3,56$ & 1 \\
\hline$<5$ tahun & 37 & 82,2 & 38 & 84,4 & & & \\
\hline \multicolumn{8}{|l|}{ Riwayat DM } \\
\hline Ada & 24 & 53,3 & 13 & 28,9 & 2,81 & $1,18-6,72$ & $0,032 *$ \\
\hline Tidak & 21 & 46,7 & 32 & 71,1 & & & \\
\hline \multicolumn{8}{|l|}{ Riwayat Hipertensi } \\
\hline Ada & 30 & 66,7 & 16 & 35,6 & 3,63 & $1,52-8,65$ & $0,006^{*}$ \\
\hline Tidak ada & 15 & 33,3 & 29 & 64,4 & & & \\
\hline \multicolumn{8}{|l|}{ Riwayat Kolesterol } \\
\hline$\geq 240 \mathrm{mg} / \mathrm{dL}$ & 15 & 33,3 & 9 & 20 & 2.00 & $0,77-5,21$ & 0,233 \\
\hline$<240$ & 30 & 66,7 & 36 & 80 & & & \\
\hline \multicolumn{8}{|c|}{ Riwayat Kadar Trigliserida tinggi } \\
\hline$>150 \mathrm{mg} / \mathrm{dL}$ & 22 & 48,9 & 13 & 28,9 & 2,36 & $0,99-5,62$ & 0,084 \\
\hline$\leq 150 \mathrm{mg} / \mathrm{dL}$ & 23 & 51,1 & 32 & 71,1 & & & \\
\hline \multicolumn{8}{|c|}{ Riwayat HDL-Kolesterol rendah } \\
\hline$<40 \mathrm{mg} / \mathrm{dL}$ & 30 & 66,7 & 13 & 28,9 & 4,923 & $2,01-12,04$ & $0.001 *$ \\
\hline$\geq 40 \mathrm{mg} / \mathrm{dL}$ & 15 & 33,3 & 32 & 71,1 & & & \\
\hline \multicolumn{8}{|c|}{ Riwayat LDL-Kolesterol tinggi } \\
\hline$>130 \mathrm{mg} / \mathrm{dL}$ & 23 & 51,1 & 21 & 46,9 & 0,44 & $0,44-2,29$ & 0,833 \\
\hline$\leq 130 \mathrm{mg} / \mathrm{dL}$ & 22 & 48,9 & 24 & 53,3 & & & \\
\hline \multicolumn{8}{|c|}{ Riwayat Lama Diabetes Mellitus } \\
\hline$\geq 5$ tahun & 22 & 48,9 & 7 & 5,6 & 5,19 & $1,92-14,06$ & $0,002 *$ \\
\hline$<5$ tahun & 23 & 51,1 & 38 & 4,4 & & & \\
\hline \multicolumn{8}{|l|}{ Riwayat Lama Hipertensi } \\
\hline$\geq 5$ Tahun & 24 & 53,3 & 4 & 8,9 & 11,71 & $3,59-38,20$ & $0.000 *$ \\
\hline$<5$ Tahun & 21 & 46,7 & 41 & 91,1 & & & \\
\hline \multicolumn{8}{|c|}{ Riwayat Lama Dislipidemia } \\
\hline$\geq 5$ tahun & 19 & 42,2 & 7 & 15,6 & 3,97 & $1,46-10,78$ & \\
\hline$<5$ tahun & 26 & 57,8 & 38 & 84,4 & & & \\
\hline Total & 45 & 100 & 45 & 100 & & & \\
\hline
\end{tabular}

$*$ nilai $\mathrm{p}<0,05$ 
Hasil uji bivariat Chi-Square mendapatkan 6 variabel yang berhubungan $(p<0,05)$ terhadap kejadian PGK terminal yaitu ; riwayat diabetes mellitus, riwayat hipertensi, riwayat HDL-kolesterol rendah $<40 \mathrm{mg} / \mathrm{dL}$ (L) / < $35 \mathrm{mg} / \mathrm{dL}(\mathrm{P})$, riwayat lama diabetes mellitus $\geq 5$ tahun, riwayat lama hipertensi $5 \geq$ tahun, dan riwayat lama dislipidemia $\geq 5$ tahun. Hasil uji bivariat mendapatkan 9 variabel dengan $p<0,25$, sehingga layak masuk ke dalam analisis multivariat. Hasil analisis multivariat terhadap 9 variabel dengan nilai $p<0,25$ disajikan pada Tabel 4 .

Tabel 4. Hasil Uji Multivariat Terhadap Variabel dengan Nilai $p<0,25$

\begin{tabular}{|c|c|c|c|c|}
\hline Variabel & B & OR & $95 \% C I$ & $P$ \\
\hline $\begin{array}{l}\text { Riwayat kel. menderita sindrom } \\
\text { metabolik }\end{array}$ & 0,222 & 1,25 & $0,40-3,92$ & 0,704 \\
\hline Riwayat diabetes mellitus & $-0,940$ & 0,39 & $0,07-2,29$ & 0,298 \\
\hline Riwayat hipertensi & 0,513 & 1,67 & $0,46-6,06$ & 0,435 \\
\hline $\begin{array}{l}\text { Riwayat kadar kolesterol total tinggi } \\
(>240 \mathrm{mg} / \mathrm{dL})\end{array}$ & 0,123 & 1,13 & $0,23-5,51$ & 0,879 \\
\hline $\begin{array}{l}\text { Riwayat kadar trigliserida tinggi } \\
(\geq 150 \mathrm{mg} / \mathrm{dL})\end{array}$ & $-0,137$ & 0,88 & $0,23-3,30$ & 0,839 \\
\hline $\begin{array}{l}\text { Riwayat kadar HDL-kolesterol rendah } \\
(\mathrm{L}<35 \mathrm{mg} / \mathrm{dL}, \mathrm{P}<40 \mathrm{mg} / \mathrm{dL})\end{array}$ & 1,139 & 3,12 & $1,08-9,04$ & $0,036^{*}$ \\
\hline Riwayat lama menderita $\mathrm{DM} \geq 5$ th & 1,346 & 3,84 & $1,20-12,30$ & $0,023^{*}$ \\
\hline Riwayat lama menderita hipertensi $\geq 5$ th & 2,388 & 10,89 & $3,08-38,60$ & $0,000 *$ \\
\hline Riwayat lama menderita dislipidemia $\geq 5$ th & 0,024 & 1,03 & $0,15-6,88$ & 0,980 \\
\hline
\end{tabular}

* Variabel yang terbukti sebagai faktor risiko dengan nilai $\mathrm{p}<0,0$

Variabel yang terbukti berhubungan dan menjadi faktor risiko paling tinggi adalah lama hipertensi $\geq 5$ tahun dengn nilai (OR $=10,89 ; 95 \% \mathrm{CI}=3,08-38,60$ dan $p=0.000$ ). Hal ini menandakan bahwa individu dengan riwayat menderita hipertensi $\geq 5$ tahun mempunyai risiko 11 kali lebih besar menderita PGK stadium terminal dibandingkan individu dengan riwayat hipertensi $<5$ tahun. Individu dengan riwayat diabetes mellitus $\geq 5$ tahun terbukti berhubungan dan menjadi faktor risiko tertinggi kedua dengan $(\mathrm{OR}=3,84$; 95\% CI=1,20-12,30 dan $p=0,023)$. Hal ini berarti individu yang mempunyai riwayat menderita diabetes mellitus $\geq 5$ tahun mempunyai risiko 4 kali lebih besari untuk menderita PGK stadium terminal dibandingkan dengan individu yang menderita diabetes melitus $<5$ tahun.
Variabel yang terbukti berhubungan dan menjadi faktor risiko tertinggi ketiga adalah riwayat HDL-kolesterol rendah $(<35 \mathrm{mg} / \mathrm{dL}(\mathrm{L})$ dan $<40 \mathrm{mg} / \mathrm{dL}(\mathrm{P}))$ dengan nilai $(\mathrm{OR}=3,12$; $95 \% \mathrm{CI}=1,08-9,40 ; p=0,036)$. Individu yang mempunyai riwayat HDL-kolesterol rendah mempunyai risiko 3 lebih tinggi untuk memenderita penyakit ginjal kronik terminal dibandingkan individu dengan riwayat HDLnormal/tinggi (laki-laki $\geq 35 \mathrm{mg} / \mathrm{dL}$, perempuan $\geq 40 \mathrm{mg} / \mathrm{dL}$ ).

\section{Pembahasan}

Penelitian ini mendapatkan penderita PGK terminal lebih banyak yang berjenis kelamin laki-laki daripada perempuan. Beberapa penelitian mengenai hubungan jenis kelamin dengan kejadian PGK terminal mendapatkan hasil yang berbeda-beda. Diduga kuat hanya karena perempuan lebih memperhatikan kesehatan daripada laki-laki. 
Berdasarkan jenis pekerjaan, penderita PGK terminal paling banyak tidak bekerja/pensiun dengan jumlah 18 orang $(17,8 \%)$. Hal ini kemungkinan karena risiko PGK meningkat pada usia > 50 tahun dan pada usia tersebut seseorang sudah mendekati usia pensiun. Tingkat pendidikan penderita PGK terminal terbanyak adalah SMA/sederajad, sebanyak 19 orang $(42,2$ $\%$ ), dan paling sedikit SMP sebanyak 2 $(4,4 \%)$. Responden dengan tingkat pendidikan rendah kemungkinan kurang mempunyai kesadaran berobat, sehingga hanya didapatkan sedikit pada penelitian ini.

\section{Hasil Wawancara Mendalam}

Hasil wawancara mendalam diketahui bahwa responden penderita PGK terminal pada umumnya tidak mengetahui faktor risiko penyakit ginjal kronik terminal. Responden tidak mengetahui bahwa sindrom metabolik yang tidak terkontrol akan menyebabkan progresivitas penyakit menjadi ginjal kronik terminal. Responden tidak rutin periksa dan tidak rutin mengkonsumsi obat. Sebaliknya responden beranggapan jika minum obat dalam jangka waktu panjang dapat merusak ginjal.

\section{Komponen Sindrom metabolik yang Terbukti Menjadi Faktor Risiko Kejadian PGK Terminal}

\section{Variabel Lama Hipertensi $\geq 5$ Tahun}

Batasan lama menderita hipertensi dalam penelitian ini $\geq 5$ tahun. Suatu tenggang waktu yang lebih pendek dari beberapa penelitian sebelumnya. Hal ini disebabkan temuan pada kelompok kasus terdapat $22(48,9 \%)$ responden yang mepunyai riwayat hipertensi $\geq 5$ tahun sedangkan $23(51,1 \%)$ menderita hipertensi $\leq 5$ tahun.

Variabel riwayat lama menderita hipertensi $\geq 5$ tahun terbukti berhubungan dan menjadi faktor risiko tertinggi terhadap kejadian PGK terminal. Hasil ini sejalan dengan analisis Adha Nurjanah yang mendapatkan bahwa pada lama hipertensi $>10$ tahun resiko terjadinya PGK terminal lebih tinggi dibandingkan dengan yang memiliki lama hipertensi 6-10 tahun dan 1-5 tahun $(p=0,001)^{(12)}$ Penelitian lain yang mendapatkan hasil sama adalah penelitian Hidayati et.al yang menyimpulkan bahwa semakin lama menderita hipertensi maka semakin tinggi risiko terjadinya PGK terminal ${ }^{13}$

Menurut WHO tekanan darah sistole $\geq$ $140 \mathrm{mmHg}$ dan diastole $\geq 90 \mathrm{mmHg}$ termasuk katagori hipertensi dan merupakan salah satu penyebab PGK terminal melalui suatu proses yang mengakibatkan hilangnya sejumlah besar nefron fungsional yang progresif dan irreversible. Peningkatan tekanan dan regangan yang kronik pada arteriol dan glomeruli diyakini dapat menyebabkan sklerosis pada pembuluh darah glomeruli atau yang sering disebut dengan glomerulosklerosis. Perubahan fungsi ginjal dalam waktu yang lama dapat mengakibatkan kerusakan lebih lanjut pada nefron yang ada. Lesi-lesi sklerotik yang terbentuk semakin banyak sehingga dapat menimbulkan obliterasi glomerulus, yang mengakibatkan penurunan fungsi ginjal lebih lanjut, dan menimbulkan lingkaran setan yang berkembang secara lambat yang berakhir sebagai penyakit ginjal terminal. ${ }^{14}$ Apabila penderita mengalami komplikasi beberapa komponen sindrom metabolik dan tidak mendapat intervensi yang sesuai akan menyebabkan terjadinya PGK terminal dalam waktu 5-10 tahun. ${ }^{4,15}$

\section{Riwayat Lama Menderita Diabetes Mellitus $\geq 5$ Tahun}

Riwayat lama menderita diabetes mellitus $\geq 5$ tahun dalam analisis multivariat terbukti berhubungan dan menjadi faktor risiko kejadian PGK terminal. Molitch mengatakan antara 20\% dan $30 \%$ dari pasien dengan DM tipe-1 atau DM tipe-2 akan mengembangkan penyakit ginjal diabetes selama hidup mereka. ${ }^{16,17}$. Tanpa intervensi yang spesifik, 50\% dari pasien dengan DM-1 dan dengan kelainan ginjal (protein urine $\geq 300 \mathrm{mg} / 24$ jam) akan melaju 
menjadi stadium akhir, dalam waktu 10 tahun dari onset, dan > $75 \%$ menjadi PGK terminal setelah 20 tahun. $^{18}$

Penelitian lain menunjukkan bahwa antara lama menderita diabetes dengan LFG diperoleh $p=0,971>0,05$ yang menandakan bahwa tidak ada hubungan yang bermakna antara lama DM dengan penurunan LFG pada penderita PGK. ${ }^{19}$ Penelitian dari Ari winako mendapatkan hasil bahwa lama DM tidak berhubungan dengan kejadian PGK-DM. (OR=5,07; 95\% $\mathrm{CI}=0,86-29,86 ; p=0,073){ }^{20}$

Hiperglikemi yang tidak terkontrol pada penderita DM akan menyebabkan progresivitas DM menjadi nefropati diabetikum. Menurut Silvia, nefropati diabetikum stadium 2 terjadi sekitar 5 tahun setelah awitan diabetes tipe 1 dan akan berkembang pada semua jenis diabetes. Dalam waktu 10 tahun jika diabetes tetap tidak terkontrol akan berkembang menjadi stadium 3.

Stadium 4/fase nefropati diabet klinis yang ditandai dengan makroalbuminuria / proteinuria yang menetap $(>300 \mathrm{mg} / 24$ jam) menyebabkan penurunan GFR yang progresif, retinopati diabetik. Pada kondisi ini hipertensi akan muncul setelah 15 tahun setelah awitan diabetes. Fase PGK terminal yang ditandai dengan Azotemia akan terjadi sekitar 20 tahun dari awitan diabetes. Kecepatan penurunan GFR $1 \mathrm{ml} /$ bulan, sehingga PGK terminal akan muncukl 5-10 tahun setelah awitan proteinuria. ${ }^{21}$

Progresivitas mungkin bisa dicegah dengan kontrol gula darah dan tekanan darah yang ketat. ${ }^{22}$

Pada komplikasi nefropati diabetik terjadi peningkatan glomerulus dan disertai peningkatan matriks ekstraseluler dan menyebabkan terjadinya penebalan membran basal ekspansi mesangial dan hipertrofi glomerular, kemudian menyebabkan berkurangnya area filtrasi dan selanjutnya mengarah pada glomerulosklerosis. ${ }^{23}$

\section{Riwayat Kadar High Density Lipoprotein-C/HDL Rendah \\ Kolesterol}

Hasil multivariat mendapatkan riwayat HDL-kolesterol rendah ( $<35 \mathrm{mg} / \mathrm{dL}$ (L) dan (P) $<40 \mathrm{mg} / \mathrm{dL}$ ), mempunyai hubungan yang signifikan dan terbukti sebagai faktor risiko PGK terminal. Hasil ini sejalan dengan penelitian Nosratola D.Vaziri yang mendapatkan hubungan bermakna antara penurunan HDL dengan kejadian PGK terminal $(p<0,05) .{ }^{24}$ Sedangkan penelitian Ari Winarko mendapatkan adanya hubungan pada uji bivariat namun pada uji multivariat terbukti tidak menjadi faktor risiko $(p=0,074){ }^{25}$

Suatu penelitian physician health (19821996) mendapatkan kadar HDL-kolesterol yang rendah menyebabkan peningkatan kreatinin > 1,5 $\mathrm{mg} / \mathrm{dL}$ dan penurunan creatinin clearance sampai $<55 \mathrm{ml} /$ menit. Sedangkan pada penelitian Helsinki heart didapatkan subyek dengan ratio LDL/HDL (> 4,4 ) terjadi penurunan fungsi ginjal $20 \%$ lebih tinggi dibanding pada subyek dengan ratio 3,2.

Penyakit ginjal kronik terminal memiliki hubungan yang signifikan dengan berkurangnya HDL-kolesterol atau serum apolipoprotein A-I (apoA-I). Berkurangnya apoliprotein menyebabkan berkurangnya kemampuan pembersihan plak, peningkatan inflamasi dan proses oksidasi yang mempermudah rusaknya sel sehingga memicu terjadinya arterosklerosis. Sifat Apolipoprotein-1 mimetic peptida, 4F, dapat mengurangi sifat proinflamasi dari LDLkolesteroldan meningkatkan anti inflamasi.

Konsekuensi aterosklerosis adalah penyempitan lumen pembuluh darah yang menyebabkan suplai darah ke ginjal berkurang. Selanjutnya akan menimbulkan gangguan proses filtrasi di Glomerulus dan pada akhirnya merusak ginjal. ${ }^{17,26}$

\section{Kesimpulan}

Faktor sindrom metabolik yang terbukti berhubungan dan menjadi faktor risiko kejadian 
penyakit ginjal kronik stadium terminal dari yang terbesar ke yang terkecil adalah ; lama menderita hipertensi $\geq 5$ tahun, lama menderita diabetes mellitus $\geq 5$ tahun dan high-density lipoprotein (HDL)-kolesterol rendah. Individu dengan tiga riwayat kondisi klinis tersebut mempunyai kemungkinan menderita PGK terminal sebesar $96,3 \%$.

\section{Ucapan Terimakasih}

Terimaksih kepada pihak RSUP dr.Kariadi dan RSU Kota Semarang telah memberi kesempatan lokasi penelitian.

\section{Daftar Pustaka}

1. Price S, Wilson LM, Konsep Klinis Prinsip Proses Penyakit. 6th ed. Hartanto H, Susi N, Wulansari P, Mahanani DA, editors. Jakarta: EGC; 2006. 913-991p.

2. Isselbacher, Braunwald, Wilson, Martin, Fauci A, Kasper K. Harrison: Prinsip-Prinsip Ilmu penyakit Dalam. 3rd ed. Ahmad HA, editor. Jakarta: EGC; 2000;1435-1437p.

3. Unitade State Renal data System (USRDS). Annual Data Report: Mortality Of End Stage Renal Disease. 2015;2:219-226 p.

4. Kemenkes RI. Penyakit Tidak Menular. Kementerian Kesehatan RI. 2012; 1-5p.

5. PERNEFRI. Report Of Indonesian Renal Registry 2011.4 th,ed.Jakarta. 2011;1-39p.

6. Kementerian Kesehatan Republik Indonesia. Riset Kesehatan Dasar 2013. Jakarta. 2013;106 - 111p.

7. Taal MW, Brenner BM. Predicting initiation and progression of chronic kidney disease: Developing renal risk scores. J Kidney Int [Internet]. Elsevier Masson SAS; 2006;70(10):1694- 1705p. Available from:

http://www.nature.com/ki/journal/v70/ n10/full/5001794a.html/nhttp://www. nature.com/ki/journal/v70/n1

$\underline{0 / p d f / 5001794 a . p d f}$

8. Johnson DW.Metabolic Syndrome in Severe Chronic Kidney Disease: Prevalence, Predictor, Prognosis Significance and Effect of Risk Factors Modification. J Nephrology (Carlton) 2007;12(4);391-398p.

9. NCEP. Third Report of the National Cholesterol EducationnProgram (NCEP) Expert Panel on. 01-3670 [Internet]. 2001;40-

50p. Available from:

http://www.nhlbi.nih.gov/files/docs /guidelines/atp3xsum.pdf

10. RSUP dr Kariadi Semarang. Profil RSUP dr.Kariadi Semarang www.rskariadi.co.id. 2016

11. RSUD Semarang Kota. Profil RSUD Semarang Kota. Rsud.semarangkota.go.id/. 2016;

12. Nurjanah A. Hubungan Antara Lama Hipertensi Dengan Angka Kejadian Gagal Ginjal Terminal Di Rsud Dr. Moewardi Surakarta. Naskah Publikasi. 2012

13. Hidayati T. Hubungan Antara Hipertensi, Merokok Dan Minuman Suplemen Energi Dan Penyakit Ginjal Kronis. $\quad$ http://berita-kedokteranmasyarakat.org/index.php/BKM/ar ticle/view/139. 2008;

14. Guyton A. Buku Ajar Fisiologi Kedokteran. 11 th ,ed. Jakarta: EGC; 2008;231-237p dan 326-327p

15. Ahmed S, Lowder G, Chronic Kidney Disease: Severity and Stages of Chronic Kidney Disease. 1st ed. Monika Göőz, editor. Croasia: In Tech; 2012.13-23p.

16. Costa LA, Canani LH, Lisboa HR, Tres GS, Gross JL. Aggregation of Features of the Metabolic Syndrome is Associated with Increased Prevalence of Chronic Complications in Type 2 Diabetes. $\mathrm{J}$ Diabet Med. 2004.21: 252-255 p.

17. Shah VO, Scavini M, Stidley CA. Epidemic of Diabetic and Nondiabetic 
Renal Disease among the Zuni Indians: Zuni Kidney Project. J Am Soc Nephrol 2003 ;1320-1329 p.

18. Molitch ME, DeFronzo RA, Franz MJ. Nephropathy in Diabetes. Diabetes Care 27 (Suppl 1): 2004 : 79-83p.

19. Amira N, Karel P. Hubungan Tekanan Darah dan Lama Menderita Diabetes dengan Laju Filtrasi Glomerulus Pada Subjek. 2013;1-6 p

20. Winarko A. Faktor Risiko Kejadian Penyakit Ginjal Kronik Diabetes Stadium 5 di RSI Sultan Agung Semarang dan RSUD kota Semarang. Tesis. UNDIP.2014

21. Kemenkes RI. Data dan Informasi Tahun 2014 Profil Kesehatan Indonesia. 2015;(1):1-5 p.

22. Lubis HR. Penyakit Ginjal Diabetik.In: Sudoyo AW, Setiyohadi B, Alwi I, Simadibrata, MK, Setiati S, editors. Buku Ajar Ilmu Penyakit Dalam. 4th ed. Jakarta; Bagian Ilmu Penyakit Dalam FK UI : 2006. 534$535 \mathrm{p}$.

23. Suyono S. Diabetes Melitus di Indonesia.In: Sudoyo AW, Setiyohadi B, Alwi I, Simadibrata,
MK, Setiati S, editors. Buku Ajar Ilmu Penyakit Dalam. 4th ed. Jakarta: Bagian Ilmu Penyakit Dalam FK UI; 2006;1852-1859p.

24. Vaziri ND, Moradi H, Pahl M V, Fogelman AM, Navab M. In Vitro Stimulation Of HDL Anti-Inflammatory Activity And Inhibition Of LDL ProInflammatory Activity In The Plasma Of Patients With End-Stage Renal Disease By An Apoa-1 Mimetic Peptide. J Kidney Int [Internet]. Elsevier Masson SAS; 2009;76(4):437-444 p. Available from:http://www.pubmedcentral.nih.gov /articlerender.fcgi?artid=3280585 $\&$ tool $=$ pmcentrez\&rendertype $=\mathrm{ab}$ stract

25. Winarko A. Faktor risiko kejadian penyakit ginjal kronik diabetes stadium 5 (di RSI Sultan Agung dan RSUD Kota Semarang). Tesis.UNDIP.Semarang; 2014.

26. Gotto A Wittels E. Diet, Serum, Cholesterol, Lipoprotein and Coronary Heart Disease Practical Management of The Factors Philadelphia WB Sauders Co. 1983;3. 
